\title{
The Time of Anthropology
}

Studies of Contemporary Chronopolitics

\section{Edited by}

\section{Elisabeth Kirtsoglou and Bob Simpson}

First published 2020

ISBN: 978-1-350-12582-7 (hbk)

ISBN: 978-1-003-08719-9 (ebk)

\section{Chapter 6}

\section{Monsoon uncertainties, hydro-chemical infrastructures, and ecological time in Sri Lanka}

Tom Widger and Upul Wickramasinghe

(CC BY-NC-ND 4.0)

This OA chapter is funded by Durham University, UK. 


\title{
6 Monsoon uncertainties, hydro-chemical infrastructures, and ecological time in Sri Lanka
}

\author{
Tom Widger and Upul Wickramasinghe
}

\section{Introduction}

In the first week of April 2016, the Sri Lankan president Maithripala Sirisena warned paddy farmers not to wait until after the ritually auspicious Sinhala and Tamil Alut Avurudu (New Year) at the end of the month to begin cultivation for the new season but instead to begin immediately. A combination of lower than average rainfall and higher than average temperatures throughout February and March had meant the loss of 300 million litres of water each day from the country's network of irrigation reservoirs (Perera 2016), which make up the Mahaweli Irrigation and Development Project (MDIP), the main rice-growing area of the island. Until recently, and certainly within living memory, the monsoon could have been expected to bring around 4.5 million metric tons of rain each year; over the past decade, however, seasonal rains had become unreliable, with rainfall over the Indian subcontinent decreasing between $20 \%$ and 30\% (ibid.). Speaking to Reuters news agency, Namal Karunaratne, national organiser of the All Ceylon Peasants' Federation, argued that Sri Lankan farmers were not equipped to respond to the effects of global warming. He explained, 'Our farmers are yet to get used to these changes. They are still used to the government providing water on time...They are not used to water management' (ibid.). According to Karunaratne, a clash of two forces was producing the problems experienced by farmers: the first, the pull of what he called 'tradition,' which locked farmers into a cultivation schedule premised on centrally mandated water release; the second, the push of climate change, requiring farmers to adjust their practices to an increasingly uncertain monsoon.

Despite the warnings, most farmers did decide to wait for a few weeks until after Avurudu to commence farming - by which time water levels in the tanks had fallen to $60 \%$ below their usual level. And just as Sirisena had cautioned, when farmers started preparing their lands the authorities announced water rationing across the irrigation system, with some parts receiving no issues at all. This included Kajugama, a village in 'System H' of the MDIP where we had been conducting ethnographic research into the use of chemical pesticides and fertilisers. Villagers expressed anger and 
frustration about the failure of irrigation authorities to provide them with water for the Yala season. Some complained that the government had orchestrated the water shortage, because they wanted to compel farmers in System $\mathrm{H}$ to grow riskier cash crops soya and millet, which required drier conditions, instead of rice, their staple. Others pointed out that the government had only imposed drought on System $\mathrm{H}$ because of the need to provide water for the tens of thousands of pilgrims expected to visit the nearby city of Anuradhapura over the next few months, to observe the Buddhist holy days of Vesak Poya and Poson Poya. As one informant explained:

As farmers we live according to the timetable of the Mahaweli. We can only start farming at the time decided by them, and only stop at the time decided by them. We depend for everything according to when water is released from the tank and when water is shut off again.

Others suggested the drought was an example of climate change and an increasingly erratic pattern of rainfall. 'These days we don't know when the monsoon will come. Sometimes we have drought for long periods and after that heavy rains that cause flooding,' one farmer explained. To cultivate effectively within this context, Kajugama farmers told us that they had to be 'mindful of time' (kaalaya pilibandawa salakilimath weema) if they were to beat the constraints of both the irrigation infrastructure and monsoon uncertainties - a particularly Buddhist framing that linked mental reflection with social and environmental action.

In this chapter, we contribute towards debates in the anthropology of time by highlighting the importance of what we term climate-driven ecological time in local understandings of time. If, as Kirtsoglou and Simpson note in their introductory chapter to this volume, social scientific studies of time have typically sat somewhere between three cardinal points - an objective and universal physical time, a representational and variable cultural time, and a subjective phenomenological time - we wish to argue for a fourth: a materialist time generated through the shifting relations of objects in spatial terms (Harman 2005). We argue that recent theoretical developments that have highlighted time's social and political 'thickness' (Bear 2014b) remain restricted in their capacity to understand the experience of time within more-than-human chronoscapes that inevitably impinge upon representational and phenomenological time. What we call ecological time should not be conflated with the universal, objective time of the 'natural' world. Taking our cue from 'new materialist' approaches, we consider time's metaphysics less in terms of the distinction between human and non-human time (the representational and phenomenological versus the objective universal), than we do time as the relations between objects in space (Harman 2002, 2005; Bennett 2004; Shaviro 2011).

We develop our approach through a close study of 'timeliness' as an agricultural constraint, management strategy, and climatic force in and of 
the MDIP. From an infrastructural perspective, the success or failure of the irrigation project has always pivoted on the precise alignment of two key agricultural inputs, water and fertilisers, in time. That is to say, on specific dates for water release set by the MDIP, to which the tens of thousands of farmers poised to receive water across the irrigation system should respond by applying top dressings of fertilisers. As a 'chronocratic' (Kirtsoglou \& Simpson, this volume) project whose objective was to discipline farmers into a common Mahaweli time, the MDIP has long invited discussion of the nature of time among irrigation planners and cultivators alike. We use these speculations to describe the modes of representational, phenomenological, and ecological time that exist within the MDIP's socio-techno-eco complex, at three interrelating levels - of practical farming experience; of irrigation policies and procedures; of molecular and massive material objects and processes - agrochemicals and monsoons - colliding. By one reading, the story we tell is of a historical parable of change - of how narratives of development reflect the wider contexts of their creation. In Sri Lanka, this has been in a context shaped by post-colonial politics, structural adjustment, and now looming environmental threats. By another reading, we tell a story of an infrastructure project and its multiple temporalities - from the overarching 40-year life of the MDIP itself, to the everyday practicalities of trying to ensure water and fertilisers converge in the right place at the right time. These two stories offer a view of repeated attempts to generate time-discipline among Mahaweli farmers, in a context fundamentally shaped by ecological pressures that make this practicably impossible. We propose that the concept of modern time as embodied in the MDIP describes what we call a restricted sociology of time, but that by paying attention to an expansive ecology of time, as embodied in farmers' attempts to become mindful of 'water time' and 'fertiliser time,' can help to illuminate the impacts of climate change on local temporal understandings.

Ethnographic research was conducted in a village we call Kajugama, in System H of the MDIP, between November 2015 and August 2016. We lodged with a local family and conducted household surveys across the community, during which we recorded, inter alia, views on agricultural challenges and problems. This produced detailed records on 59 farmers, which we then fleshed out by conducting in-depth follow-up interviews with around ten farmers, and two focus group discussions on recurring themes, including water management and the problem of timeliness, containing 12 farmers each. Finally, our long-term participation in social life in Kajugama facilitated the development of a more quotidian and textured set of understandings of how farmers went about agricultural activities within the Mahaweli, including how they planned farming during times of water shortage and monsoon uncertainties. We also spent several months working through the holdings of the Mahaweli Library and the Hector Kobbekaduwa Agrarian Research and Training Institute, both in Colombo, which store technical, evaluation, and policy reports on the MDIP including System H. Those 
sources helped us to historicise the ethnographic insights we had gained, showing how farmers' concerns with timeliness had emerged in the context of wider policy efforts to effect exactly such change.

\section{The anthropology of time: from culture to cognition to ecology}

Anthropologists have long been interested in how human experiences of time are shaped by, and shape, socioeconomic, cultural, and ritual contexts (Goody 1968; Gell 1992; Munn 1992; Hughes and Trautmann 1995; Bear 2014a). Across the course of the twentieth century, anthropological interest in the ethnographic variance of human understandings of time led to a growth of models that Alfred Gell (1992) criticised for engaging in 'unwarranted metaphysical speculation' (ibid.: 149). By this, Gell meant that the cultural-symbolic approach to time that anthropologists had generally employed lacked a clear epistemology and a 'generalized sense of puzzlement that the ghostly notion of time evokes' (ibid.). Writing against this trend, Gell argued that time existed not only in a universal and objective sense but also for the purpose of anthropological analysis; it was only necessary to consider actor-oriented experiences of time and socio-cultural representations of time - what Gell, after McTaggart, called 'A-series' and 'B-series' models of time, respectively (ibid.: 149-174). The A-series equated with subjective time, which is to say something that passes from the future, through the present, to the past, as a series of relative moments, and the B-series with the structural mechanism of time, external to the individual, which places things 'before' and 'after' in an absolute sense, unconnected to the temporal location of the actor. For Gell, the subjective A-series and structural B-series both manifest on the level of cognitive 'time-maps' that produced temporal representations which aided human beings to navigate the social world.

Extending Gell's ideas, Laura Bear (2014b) has argued that what Gell had proposed as cognitive tools could also be understood as cultural phenomena linked to economic, social, and political institutions, characterised by 'affect and deep temporal depth' (ibid.: 17). In global capitalism, Bear suggested that the dominant model of time is an abstract time-reckoning model used to measure value structurally - what amounts to a B-series time-map in Gell's parlance. But, argues Bear, this model also exists alongside a plurality of A-series time-maps from which modern institutions (banks, corporations, and so on) all pull to produce a diverse array of 'representations, techniques, and rhythms of human and non-human time.' For Bear, this very diversity of time-maps in the making of capitalist time suggests that 'modern time is characterized by unprecedented doubt about, and conflict in, representations of time' (ibid.). As institutions seek to manage diverse temporalities, time 'thickens with ethical problems, impossible dilemmas, and difficult orchestrations...[as]...the irreconcilable social rhythms produced by the use of abstract time are laid bare' (ibid.: 7, 17). 
Importantly, Bear's concern to describe 'modern' time produced by and productive of political economic processes involved a rejection of Latour's (1993) contention that 'we have never been modern.' Bear argued that a concept of modernity was crucial to retain if anthropologists were to make sense of global capitalist timespace. In so doing, Bear was also rejecting the potential for thinking beyond anthropocentric terms, explaining away what we have termed ecological time as an 'attempt to project and combine human and non-human forms of time' (Bear 2014b). Yet we argue that a concern with modernity as such limits anthropologists to considering only the economic, political, and bureaucratic representations and techniques of time - what we have called the restricted sociology of time. As we describe below, the functional limits of the MDIP as a hydro-chemical infrastructure straining to adjust to monsoon uncertainties highlights the environmental context of human temporalisation within a social-techno-eco complex of non-human objects pulling together and falling apart in a process that exceeds political economic and political ecological forces - necessitating a 'post-modern' approach to time. This view requires a deeper theorisation of the potentialities of what is usually fenced off from the time of anthropology the functioning of the natural world that obeys Newtonian rules.

Perhaps for many anthropologists, the knowledge that real time exists as a constant has offered a feeling of ontological security in the face of what Gell dismissed as descriptions of time in ethnographic 'fairyland' (1992: 314). To deny those 'others' who seemingly experienced time differently from 'us' was moreover to deny them 'coevalness' (ibid.), which is to say to relegate them to some pre-modern or a-modern time. As Kirtsoglou and Simpson (this volume) also suggest, such denials also lay at the core of the chronocratic workings of political and economic systems, with various forms of time-othering producing 'deeply asymmetrical relationships of exclusion and domination' between those who control time and those who are subject to time. In what follows, we extend these debates by showing how a concern with chronocracy does not preclude an interest in time of the non-human but in fact is essential if anthropology is to say anything meaningful about the workings of political and economic systems in the context of climate crisis. The objective of our critique, then, is both to unsettle the ontological security that may derive from the notion of universal time and to enter willingly the 'fairyland' of non-human time that new materialist approaches can offer. Before developing these ideas, however, we will describe time as it is lived and managed in the Mahaweli.

\section{Waiting for water in Kajugama: systemic and climatic constraints on farming}

Throughout our research in Kajugama, it became increasingly clear how local farmers have long struggled with the water release schedules maintained by the MDIP. The problem was not that the MDIP had always provided 
water on time but, to the contrary, that it always had not. Farmers viewed this not just as an administrative failing of the Mahaweli authorities but also as an issue spanning multiple domains of social and cultural structure, practice, and action. These included the constraints inherent in the irrigation infrastructure itself, through farmers' agrarian knowledge and skills, to the effects of climate change. The coming of the rains was also associated with the actions of deities. Our Kajugama informants saw a close approximation between the righteousness of people - in the village, in System $\mathrm{H}$, in the world as a whole - and the chance of rain falling or not (c.f. Weeratunge 2000: 254). More widely, farmers' imbued water with significant historical, social, and religious meaning. Their occupational status as govi (farmers), caste status as goyigama (people who work the soil), and identities as Sinhala Buddhists residing in the cultural heartland of Anuradhapura all depended on the availability of water to grow paddy. Discussing the impact of the MDIP's decision to halt water to System H, one farmer explained, 'we have to grow rice as that is who we are. If we can't grow rice then there is no use in farming any longer. We don't want to grow maize or those other things.'

For Kajugama farmers, this 'cultural' account of water's potential abundance conflicted with the experience of water as a scarce resource that only flowed according to MDIP schedules. In Kajugama, farmers grew rice using the seed broadcast method. To kill weeds and to soften the ground, the field would be flooded and then ploughed prior to seeding. Water was again needed at two further dates in the growing season, when top dressings of fertiliser would be applied - for the samba rice variety, which was most extensively grown in Kajugama, this would be after 14 and 28 days. To meet these demands, each section of System $\mathrm{H}$ would receive three water issues at different times, with each water issue lasting 14 days (i.e. water would flow through each section's canals and down to individual fields for 14 days at a time). The problem that farmers faced was first ensuring they were ready to receive water issues to flood, weed, and plough their field, and then ensuring their paddy had developed sufficiently for the effective application of fertiliser to coincide with later water issues. Kajugama farmers explained that the date on which they typically received the first water issue and the length of time for which they received water issues were both unsuited to their needs.

Moreover, the different climate conditions characterising the two growing seasons of the year affected the nature of the challenge that farmers faced. The Maha season, which corresponds with the northeast monsoon from September to March, is typically wetter than the Yala season, which corresponds with the southwest monsoon from May to the end of August. During Maha, the MDIP usually released water in November, once the rains have begun to replenish the storage tanks that had been depleted during the previous season. During Yala, water would only be released once the inter-monsoonal rains that fell after Maha had replenished the tanks, usually sometime by early May. Even though one of the original aims of 
the Mahaweli project had been to alleviate precisely this dependence upon rainfall, the storage and distribution system had never adequately met the ever increasing demands for water - and in recent years the increasing unpredictability of rains.

A related problem involved the cycling of water between subsystems, resulting in farmers receiving water issues only for a maximum of 14 days at a time. This meant that farmers had to condense land preparation for both seasons into a shorter period than they felt was required. Consequently, windows of opportunity for applying fertiliser often did not correspond with the optimal stage of plant growth. The result was often that water arrived later in the growing season than it was needed, at a time when rice plants were under- or over-developed for optimal fertiliser application. To try to mitigate this, farmers explained how they 'rushed' land preparation and often began seeding before they had managed to kill all the weeds. As it happens, the 2015 Maha season also coincided with the Sri Lankan government's ban of the herbicide glyphosate, which farmers said they depended upon as the quickest and most cost effective way of clearing their fields of weeds that had grown since the end of the Yala season earlier that year. Describing the situation one farmer explained:

We get water in November and within fifteen days we have to finish the land preparation and seeding. Otherwise, we will have water shortage issues [later in the growing season]. [But] a period of fifteen days is not enough to finish land preparation and seeding. It means the mud is not fit to grow paddy. And when we do it in a hurry, we get more diseases as well. To finish land preparation and seeding within fifteen days, then farmers need to use glyphosate to speed up weed control. Without glyphosate...there is not enough time to kill weeds, hence weeds are also growing along with paddy.

While Kajugama farmers blamed most of their troubles on the MDIP and its inability to put into practice a water release schedule, they were also aware that changing weather patterns and other environmental factors played a role. Farmers we spoke to explained how the development of the irrigation system itself had had a profound impact on ecological conditions. Extensive jungles had once covered the land around Kajugama, which the MDIP had removed to make way for the irrigation infrastructure and settlements. The trees had once had a cooling effect on the local environment, and their loss had resulted in the elevated heat and frequent droughts of present times. As one farmer described:

Deforestation is the main reason for climate changes in this country and it was significantly increased with the Mahaweli project. During the rainy season, water was retained in forest areas for several months. But now the soil becomes dry again just after the rain. 
Another explained how this led to the silting up of tanks, reducing their capacity: 'Due to deforestation, the tanks are getting filled with soil, because soil erosion has increased with the heat and then washes into the tanks.' Along with the risks of heat and drought was also an increased risk of violent rains and flash flooding. When, in May of 2016, the long period of hot and dry weather broke with torrential rains, many parts of System H were flooded when village tanks broke and floodwaters washed away homes and crops. Kajugama itself escaped devastation, but the wet conditions affected plant growth and turned an already bad Yala season into a failed one for many in the village.

Taken together, extreme heat and flash flooding compressed the window of hydro-chemical opportunity for successful farming still further. Reflecting on these issues, farmers explained how they had little choice but to accept such problems and get on with cultivation as best they could. One strategy, which was also promoted by the MDIP itself, was to make offerings to deities to counter the effect of evils in the world. Another strategy was to focus one's mind and conduct on farming - to become 'mindful' of time. In fact, the mark of a successful farmer in Kajugama was precisely one who could manage all of the uncertainties and constraints that the monsoon and the MDIP represented - a skill referred to as requiring a certain 'discipline.' Farmers spoke of the importance of 'being well aware' (honda awabodhayakin inna oni) of the need to act in unison with what they called 'water time' (watura muraya) - predicting when the MDIP was most likely to release water - and 'fertiliser time' (pohora muraya) - when would be the optimum time to dress the field. Farmers so disciplined were respected precisely because of their ability to farm during the tightest of hydro-chemical windows by exploiting to maximum effect whatever temporal advantage they had.

Chandana, aged 34, was well known in Kajugama for his farming abilities. He attracted the praise of his fellows precisely because he had mastered the uncertainties of Mahaweli time and for many represented a new generation of paddy farmers who were resisting the pull of tradition and learning to adapt to the push of global warming. Despite the drought and the failure of the MDIP to release water, in the 2016 Yala season, Chandana had heeded President Sirisena's advice and commenced cultivation before Avurudu. He manually cleared weeds and softened the soil using a little rainwater he had stored in the field by building up a bund to prevent run off. $\mathrm{He}$ planted early enough in the season to mean the rice had sufficient growth to be ready to receive fertiliser after 14 and 28 days, respectively, when some rains fell just after Avurudu. Meanwhile, other farmers in the village had only just begun weeding and ploughing by that point and hence had fallen far behind schedule. The result was that Chandana's was the only successful rice harvest in Kajugama that Yala season.

In the MDIP, temporal discipline played a crucial role in farmers' individual seasonal successes and failures as well as their longer term economic and 
social security. Off-farm actors like the MDIP may have controlled water time, but individual cultivators also had the ability to exercise agency by 'being well aware' of time. Disciplinary practices associated with becoming a 'good farmer' meant engaging with ecological processes alongside failing hydro-chemical infrastructure - an effort that required mastery over the geophysical constraints of irrigation systems themselves. As systems that depend upon gravity to pull water from tank to field, farmers at the top of distribution channels usually receive larger water issues than those at the tail end, leading to inequalities and squabbles between farmers and farmers and irrigation officials (Pfaffenberger 1990). Monsoon uncertainties have inevitably exacerbated such problems, and this combination of 'social' and 'natural' hazards can produce inequalities among farmers as some do better than others in coping with these challenges (Galt 2014). When read at this level, the meaning of time as understood by Kajugama farmers provided both a systems context to farming, a subjective discipline of farming, and a source of socioeconomic (in)security from farming. As one farmer simply put it, 'If we want to be successful in farming, then we need to do it properly. We need to apply fertilisers on time.'

\section{Sri Lankan chronocracies: a brief history of Mahaweli time}

In this section, we trace the historical development of Kajugama farmers' focus on the importance of acting according to key dates in the hydrochemical cycle as a metric of agrarian success. We show how the concern to harmonise water time with fertiliser time through disciplined agricultural practice was cultivated over decades of policy intervention, both within the irrigation zone and without, from the earliest days of the Mahaweli itself. As an expression of post-colonial chronocracy, the MDIP had seen time 'like a state' (Scott 1998) in two senses - first, by envisioning a 'tempo' for the progression of the MDIP itself; and second, by envisioning the end goal of the MDIP in either a past recreated or a future obtained. MDIP planners considered both outcomes to be achievable only through the instilling of work-time among farmers.

When work began on the MDIP in the late 1960s, the initiative held the honour of being the world's largest irrigation development project. Thirteen irrigation systems labelled 'A' to ' $M$ ' would be colonised by settler-farmers drawn from the island's south-west, as well as those displaced by Mahaweli dam and irrigation development itself. By significantly enhancing local food production, the MDIP would reduce Sri Lanka's dependence on food imports and create employment for millions of people. Indicating its scale and ambition, some $40 \%$ of the island's landmass would fall under development, with 700,000 people - more than $5 \%$ of the country's population targeted for migration (Muggah 2008). The Mahaweli Master Plan (MMP) originally envisaged a 30-year timetable to complete building works and population relocation. In 1978, the incoming president, J.R. Jayawardene, 
keen to maximise the economic and social returns of the project, accelerated the MMP to complete building works and relocations within just six years.

The decision to accelerate the project proved calamitous in several ways, including leading to huge budgetary overruns and failure to provide social infrastructure and support for settled communities (Muggah 2008: 115). Acceleration of the MMP at project implementation level also had knock-on temporal effects at community and field level, with geospatial and hydrologic planning rushed. As one Kajugama farmer explained:

There was a basic plan [for water release] before the accelerated Mahaweli programme. It was carefully planned to establish a system to release water in a required manner. The current issues [with water release schedules] are the result of the acceleration.

But if Kajugama farmers understood today's water problems to reside in the acceleration, the MDIP itself accused farmers of temporal failings of a different kind.

Just as in Kajugama today, policy discussions across the decades focussed on the barriers to fostering 'timeliness' among farmers (Mahaweli Authority of Sri Lanka 1978; Agrarian Research and Training Institute 1979). The question of why farmers struggled with timeliness and how the problem should be dealt with was answered differently during the 1980s and 1990s and after 2000. At the core of the debates were two conflicting approaches to time that can be usefully understood with reference to Gell's A-series and B-series time-maps we introduced above and his use of these to illustrate forms of social change and equilibrium identified with the temporal regimes of entrepreneurial capitalism on the one hand and agrarian feudalism on the other hand - what he termed economic A-theories and B-theories, respectively (1992: 175-182). For example, economic A-theories supported a view of capital accumulation that rested on the image of a lone entrepreneur acting moment to moment with a subjective relationship to time, such that each financial success disappeared as quickly as it appeared, generating a quenchless thirst to accumulate again. In contrast, economic B-theories explained the motivations through which landowning classes derived wealth from agricultural and plantation concerns, which depended heavily upon natural processes and only marginally on human agency. Commenting on the ideological significance of each, Gell wrote:

the B-theory generates myths that support the interests of the ruling oligarchies in agrarian societies, and equally the ruling oligarchies in centralized socialist systems; the A-theory generates myths that support the interests of the individualist entrepreneurial class which controls... non-centralized capitalist economies.

(Gell 1992: 178) 
The MDIP's approach to the problem of timeliness can be read as an attempt to implement first a set of policies inspired by economic B-theories and then, when those failed, economic A-theories. The first response sought to motivate farmers through an appeal to Sri Lanka's own history as a hydrologic civilisation, and hence we characterise it as a turn to the past. MDIP planners drew from theories of social organisation linked with the rule of water (Wittfogel 1957) and Sri Lanka's own often romanticised history as an island of hydrologic civilisations (Leach 1959; Gunawardana 1971; Harriss 1984). Developed during the first decades of post-colonial independence, the MDIP appealed to the historical and cultural sensitivities of Buddhist farmers to encourage their obedience to the Mahaweli authorities by stressing the value of water as a natural but scarce resource and the importance of acting in a timely manner to be ready for water issues. The MDIP would derive its authority in farmers' eyes from its portrayal as the natural successor to the water authorities of the past, re-establishing rice farming at the heart of Sri Lanka's Buddhist 'cultural triangle' and the foundation of the new nation.

As an example of this chronocratic endeavour, in 1979, the Sri Lankan People's Bank, a key financial backer, published Water rights and irrigation practices, a report which argued that the success of the MDIP rested upon the recreation of 'traditional' social systems that could generate ties of mutuality and cooperation between farmers. The report argued 'there is a need that farmers be taught the importance of group action and proper water use' (People's Bank 1979: 29). The report further argued that farmers did not value water, because they received it free of charge - for farmers, water was a "'Gift of the Gods"; it is not to be charged for,' the report's authors wrote. 'Farmers need to value water like any input similar to fertilisers, labour, weedicides; rather than considering it as a free item such as air or sunshine' (ibid.: 31) they concluded. Again, the report turned to history to solve this problem, by invoking the example of a system of fines and penalties that ancient rulers had imposed on farmers found guilty of poor timekeeping. To stress this, the authors of the report signed off by quoting a stone inscription from the House of Lambakanna II (691-1017) of the Anuradhapura civilisation, which stated 'The fines to be levied...for ploughing Late, five kalandas.' The objective set out by the People's Bank report was to instil a new discipline of 'community cooperation' in farmers that would recreate the beliefs and customs of their ancestors. Only by turning to the past would the promised future of the Mahaweli bear fruit.

The turn to the past defined MDIP policies throughout the 1980s. Too extensive to report here, the several archival holdings we reviewed showed how numerous governmental and non-governmental agencies sought to develop irrigation societies at village level through which forms of 'traditional' organisation would work collectively to maintain the irrigation infrastructure to help to ensure the timely release and arrival of water and to ensure that farmers had readied their fields on time. Project evaluations we read also 
suggested that these efforts did not have the impact expected, with farmers continuing to struggle to ready their fields to match the Mahaweli timetable, which itself drifted off course almost every season. By the 1990s, however, policy responses to the problem of timeliness shifted away from a concern with the past and were developed within a new climate of donor-driven structural adjustment and agricultural liberalisation - what amounted to a turn to the future.

In 1992, the MDIP announced a Mahaweli Consolidation Project across several systems, including H (Mahaweli Authority of Sri Lanka 1992). The Consolidation Project argued for a 'joint management model' between the MDIP and farmer organisations. By directly involving farmers in the management of the system, the report argued, a large amount of money spent on irrigation rehabilitation will be in hands of the beneficiaries themselves... and they may perform higher quality of work [than private contractors] as a responsibility to their society' (ibid.: 2). Under the new arrangements, it would be the profit motive, not obedience to historical authority, which would incentivise farmers.

The clearest example of this turn to the future was the Mahaweli Restructuring and Rehabilitation Project (MRRP), launched in 1998. The MRRP was an outcome of the World Bank's Report on Structural Adjustment of Management Agencies of Sri Lanka (Mahaweli Authority of Sri Lanka 2003), a policy document (in)famous among leftist and environmental groups in Sri Lanka for heralding a new era of privatisation and liberalisation. The World Bank's aim was to implement a series of reforms that rationalised agricultural agencies in Sri Lanka as a means of increasing efficiency, productivity, and profitability. Chief within this was the objective of transforming the old Mahaweli Development Authority into a River Basin Agency (ibid.: 1).

Importantly, the MRRP identified the earlier commitment to historical authority as the cause of farmers' failure to adopt an entrepreneurial approach. Commenting on the situation found in 1998, the report warned of the

...more or less bureaucratic centralised management set up in the H system. The RPM [Resident Project Manager] was the "king"...who ruled the system...All the decisions regarding to key issues such as water, land and agriculture were taken by the key staff in the project and passed on to the farming community for implementation. But none of the decisions were implemented properly as farmers had not contributed in making such decisions with the management.

To rectify this, the MRRP sought to promote an entrepreneurial, futureoriented disposition among farmers that would eradicate what it called 'the dependency syndrome' and promote 'self-confidence' and 'empowerment' (Navaratne 2000). Specifically, the MRRP would 'challenge farmers' attitude that "[Mahaweli] officers should assist them continuously." 
It was not only within the agricultural sector, however, that attempts to instil a new future-oriented work-time discipline were to be found. In the early 1990s, Jayawardene's successor, Ranasinghe Premadasa, coined the phrase 'Lankave velaava' ('Sri Lanka time') to describe the limits placed on national development by what he perceived as Sri Lankans' relaxed attitude towards punctuality more generally. 'Sri Lanka time' became a key policy concern of Premadasa's presidency, finding its clearest expression in his flagship '200 Garment Factory' programme. Launched in 1992, the programme aimed to build 200 garment factories in exportoriented free trade zones and create 100,000 jobs across the island. For each garment factory built, a clock tower would also be constructed, located at the main junction closest to the factory gates, which workers would pass on their way to work and home each day. As Lynch (2007) argues, Premadasa's clock towers played a dual role - the first, helping to discipline workers to the demands of the production line and the second, to symbolize the development of Sri Lanka's rural areas as they joined 'modernity' (ibid.: 72-74).

When set within this wider policy landscape, the MDIP's turns to past and future emerge as forms of time-discipline that formed part of a more general national story - attuning the population to the functioning of infrastructure deemed crucial for Sri Lanka's entry into global markets. In 1990, Premadasa argued that:

[n]o country can make progress unless its people are dedicated and disciplined. These qualities must be built up in the home and in the school before one goes out into the world. A high standard of discipline will be enforced by imposing rules and regulations.

(Department of Government Printing, 1990: 8, cited in Lynch 2007: 76)

The post-colonial Sri Lankan state was thus a chronocratic state, foregrounding time-discipline as the pathway to social and economic modernisation - a politics of the temporal that decades later also came to characterise the immediate post-war years (Amarasuriya and Spencer 2015).

The motivations behind the Sri Lankan government's various attempts to instil a modern work-time are strongly reminiscent of Norbert Elias' sociology of time. Writing in the 1930s, Elias (1994) argued that the process through which European peoples came to view themselves as 'civilised' depended, in part, on their participation in the broad infrastructural processes of capitalist temporality. In the context of ever-expanding areas of market expansion and activity, Elias suggested, was 'the necessity for an attunement of human conduct over wider areas and foresight over longer chains of actions than ever before' (ibid.: 379). The development of capitalist infrastructures thus demanded the "strength of self-control and the permanence of compulsion...what we call the "tempo" of our time" (ibid.). For Elias, the 'tempo' of modern life was the rhythm to which we 
must all move to engage successfully with the demands of the modern world. More recently, May and Thrift (2001) have argued that the tempo of capitalism has never been a universalising but divergent process, both contested and incomplete across local contexts. Offering an analysis of temporalisation within industrial contexts, May and Thrift suggested that 'the picture that emerges is less that of a singular or uniform social time stretching over a uniform space, than of various (and uneven) networks of time stretching in different and divergent directions across an uneven social field' (ibid.: 10).

At planning level, infrastructure relies on the imposition of strict temporal uniformity among its constituent human and non-human parts to function 'properly' (that is, in correspondence with how designers' had envisaged such functioning). Through their attempts to control time (Graham and Marvin 1996: 42), hydraulic infrastructures establish temporal sensitivities of historical and spatial belonging (Mosse 2003), political citizenship and participation (Anand 2011,2012), and moralities and practices of water sharing, conservation, and wastage (Von Schnitzler 2013) - establishing common rhythms through which life should be lived and understood (Elias 1994; Dalakoglou 2010; Larkin 2013; Hetherington 2014; Reeves 2016). By the same token, 'malfunctioning' infrastructure still affects and requires temporalisation, though with effects and affects different to those that may have been anticipated. Infrastructures' interplay with ecological processes also means that infrastructural timescapes always exceed the social conditions and effects of their operation.

The MDIP's attempts to discipline farmers to Mahaweli time thus produced forms of agrarian domination and exclusion that accompany chronocratic politics. With the coming of the MDIP in the 1970s, a timescape set to the 'cultural' understanding of water and the ritual-agrarian calendar came into conflict with an abstract time attuned to the needs of intensified agricultural production within national and international rice marketplaces. Yet Mahaweli time remained a poor imitator of modern time as the MDIP had imagined it. Premadasa's garment time disciplined a waged-labour workforce to the demands of conveyor-belt production - a year-round six-day working week divided into precise units of working time, break time, and leisure time. In contrast, Mahaweli time disciplined small-scale cultivators restricted to the bi-annual six-week growing season. We suggest that it was precisely this part-time temporality of the MDIP that the alignment of water and fertilisers in time proved such a challenge. In the Mahaweli, months of time could pass without the imposition of the MDIP water timetable. There was significant possibility that Mahaweli farmers would in disciplinary terms fall out of time - from the standpoint of the MDIP schedulers as they failed to align water and fertilisers at the right time. By the time of our fieldwork in 2016 it was clear, for Kajugama farmers at least, that monsoon uncertainties had displaced the irrigation system itself as the source of time-discipline in the Mahaweli. 


\section{Sociological and ecological time in the Mahaweli}

Thus far we have described Kajugama farmers' awareness of 'water time' and 'fertiliser time' as both a contemporary strategy for paddy farming in the MDIP and as the product of a long disciplining process tied to MDIP management. The example of Chandana we gave above signals that the World Bank's attempt to promote an agentive model of agricultural accumulation has shifted temporal understandings towards what Gell called an A-theory time-map. In trying to set Mahaweli time to modern time, the MDIP also ran into numerous problems, which continue to plague Kajugama farmers to this day. Neither the B-theory model based on the turn to the past nor the A-theory model based on the turn to the future offered the MDIP the solution for which it had been searching. We see this today in the fact that most Kajugama farmers felt unwilling to act spontaneously in the way that the A-theory model supposes. Mahaweli time exceeded both economic Atheory and B-theory because time as the MDIP envisaged it was premised on what we call a restricted sociology of time - that is, a model of time that did not account for ecological processes. Absent from the analysis was the third looming actor of the monsoon itself and its interactions with hydro-chemical infrastructures.

The temporal foibles of the MDIP illuminate too the limits of anthropologists' attempts to bracket off universal time from serious ethnographic inquiry. Taking the monsoon seriously (along with other things) helps us to understand better the actions of Kajugama farmers by reading their decisions within an expanded time-space that sought to account for and control the interplay of material forces and things that had significant temporal effects, and which did not privilege the human over any other actor in the complex of things that affected agriculture. To farm effectively in the Mahaweli has increasingly meant acting beyond human temporal scales to engage productively beyond the horizon of human time in the expansive ecology of irrigated agriculture. This has required engaging with the vanishingly small of chemical fertilisers (which functioned on the presence of water atop soil to activate bio-chemical processes) and the momentously large of the monsoon (the dynamics of climate change) - entities that in combination exert a 'gravitational pull' on relations in the world - what Morton (2013) calls 'hyper-objects.'

Our ethnographic investigation of ecological time requires paying attention to how the ordering and reordering of objects in and of the Mahaweli is the passage of time itself. Graham Harman (2005) has asked why so much attention has been paid to the question of whether humans can travel backwards in time, and when the question of whether we can travel backwards in space has been entirely taken for granted? For Harman, space, what he terms the 'regime of objects,' is itself unchanged by the passage of time, which has no effect whatsoever upon the ontological and relational structure of things themselves. As Harman argues (ibid.: 252), '[t]ime itself creates 
nothing, while spatial changes create lasting monuments...what we are measuring when we measure progression are changes in the actual regime of objects, also known as changes in space.' Change in the regime of objects not only marks but also generates time passing - time is to be understood as the effect of shifting spatial relations. (And because it is impossible to ever perfectly recreate any particular configuration in the regime of objects, it is perforce impossible to ever travel back in space....)

We have seen how shifting chronocratic regimes of water and fertiliser management compelled changing regimes of temporal discipline. If we view the passing of time in terms of the shifting arrangements of objects, we can see how Mahaweli time has been generated from the rearrangements of people, hydro-chemical infrastructure, and monsoons, rather than those things having been changed by time passing. If so, then the three cardinal points of time - universal, representational, and subjective - are not sufficient to understand time as they inevitably rely on a human vantage point for triangulation. To overcome this we need to pay attention to the ecology of objects and their relative positions and relations as the generative origin of time. The 30-year history of the MDIP we have just related can thus be read at the level of material relations between things - water, fertilisers, farmers, fields, forests, rice plants, policy briefs, presidents, the People's Bank, and the World Bank. Within this complex of things, the monsoon has emerged as an increasingly important influence in setting Mahaweli time as it has impinged upon the relative positions and relations between all these things that make up paddy cultivation in Sri Lanka. This is what we have called ecological time.

\section{Conclusion}

Anthropological models of time that take their epistemological roots for granted do not describe human time well, and the same problem restricts models that take the ecological for granted. In this chapter, our basic argument has been that recent anthropological discussions of time have pushed theorisation into productive new areas but have still not adequately overcome the baggage of the discipline's own intellectual history, which remains rooted in modern social theory. We took up positions developed by Alfred Gell and Laura Bear to demonstrate this view, using the example of the ways in which the MDIP itself has planned time through an industrial rubric to show what an anthropology of 'modern' time overlooks. We showed how in response to the long crisis of water and agrochemical management, the MDIP sought to instil a new work-discipline of timeliness, yet used models of time drawn from industrial capitalism when doing so. Our engagement with the ideas of Norbert Elias proved useful in showing just how similar was the reasoning between various Sri Lankan presidents and modern social theorists - and how by focussing on the level of human action, the MDIP failed to register that it was also chemical fertilisers and monsoons, not only irrigation engineers or farmers, which structured Mahaweli time. 
We argued that anthropological discussions of time will remain limited if alongside human time we do not also consider that which falls beyond - the expansive ecologies of time. A study of time in agricultural contexts like the MDIP, which sit at the forefront of clashes caused by the meeting of Green Revolution technologies and monsoon uncertainties, necessarily must reset the underpinning assumption of the tempo and scale of agricultural work. Discussions of human time cannot contain the implications of temporal pressures that the climate crisis puts to bear on farmers, especially in the developing world. Here, we found the 'new materialist' approach of Graham Harman useful when seeking to move the discussion forward to considering what an approach to non-human time might involve.

We do not mean for ecological time to replace social-modernist approaches but for it to offer an additional perspective that helps us to situate human beings within changing timescapes of experience. With the dawn of the Anthropocene as both a context of anthropology and a problem for anthropology, Amelia Moore (2016) has urged us to pay attention to the 'spaces' of human encounter with geo-climatic processes. We also urge our readers to pay attention to the temporalities of the Anthropocene. These temporalities invite consideration of not just when these encounters take place but where within the 'regime of objects'. They also draw attention to the dispositions and disciplines of time necessary for effective and affective attunement to (Latourian) networks of action that exceed the level of human agency, and the processes, often invisible, at work both under foot and above our heads. For Kajugama farmers, attunement was, for the most part, simply an impossible goal; agricultural work-time meant embracing uncertainty and chance as a technocratic problem as much as it did a close knowledge of the capacities and capabilities of one's own field and effective appeals to deities. For infrastructure projects like the MDIP, it means finding ways of thinking policy beyond economic A- or B-theories and asking what kinds of knowledge and skills Mahaweli farmers will require if they are to adjust effectively to climate-sensitive timetables. For anthropologists, exploring how people and institutions negotiate the relationship between sociological and ecological time offers scope for better understanding how and where cognitive and social time-maps interface with non-human time, which itself we must now accept falls within the purview of anthropological investigation.

\section{References}

Agrarian Research and Training Institute. 1979. "An Analysis of the Pre-Mahaweli Situation in H4 and H5 Areas in Kala-Oya Basin." Research Study No. 33. Colombo.

Amarasuriya, Harini, and Jonathan Spencer. 2015. "With That, Discipline Will also Come to Them." Current Anthropology 56(S11): S66-S75. https://doi.org/ $10.1086 / 681926$. 
Anand, Nikhil. 2011. "Pressure: The PoliTechnics of Water Supply in Mumbai." Cultural Anthropology 26(4): 542-564. https://doi.org/10.1111/j.1548-1360.2011.01111.x.

2012. "Municipal Disconnect: On Abject Water and Its Urban Infrastructures.” Ethnography 13(4): 487-509. https://doi.org/10.1177/1466138111435743.

Bear, Laura. 2014a. Doubt, Conflict, Mediation: The Anthropology of Modern Time. Edited by Laura Bear. Hoboken, NJ: Wiley-Blackwell.

- 2014b. "Doubt, Conflict, Mediation: The Anthropology of Modern Time." Journal of the Royal Anthropological Institute 20(S1): 3-30. https://doi. org/10.1111/1467-9655.12091.

Bennett, Jane. 2004. "The Force of Things: Steps toward an Ecology of Matter." Political Theory 32(3): 347-372. https://doi.org/10.1177/0090591703260853.

Dalakoglou, Dimitris Dimitrios. 2010. "The Road: Ethnography of the AlbanianGreek Cross-Border Motorway.” American Ethnologist 37(1): 132-149. https://doi. org/10.1111/j.1548-1425.2009.01246.x.

Elias, Norbert. 1994. The Civilizing Process: Sociogenetic and Psychogenetic Investigations. Translated by Edmund Jephcott. Revised Edition. Oxford: Blackwell Publishing.

Galt, Ryan E. 2014. Food Systems in an Unequal World: Pesticides, Vegetables, and Agrarian Capitalism in Costa Rica. Tuscon: University of Arizona Press.

Gell, Alfred. 1992. The Anthropology of Time: Cultural Conceptions of Temporal Maps and Images. Oxford: Berg Publishers.

Goody, Jack. 1968. "Time: Social Organization.” International Encyclopeia of Social Sciences 16: 30-42.

Graham, S., and S. Marvin. 1996. Telecommunications and the City: Electronic Spaces, Urban Places. London: Routledge.

Gunawardana, R. A. L. H. 1971. "Irrigation and Hydraulic Society in Early Medieval Ceylon." Past and Present 53(1): 3-27. https://doi.org/10.1093/past/53.1.3.

Harman, Graham. 2002. Tool-Being: Heidegger and the Metaphysics of Objects. Chicago and La Salle, IL: Open Court.

. 2005. Guerrilla Metaphysics: Phenomenology and the Carpentry of Things. Chicago and La Salle, IL: Open Court.

Harriss, John. 1984. "Social Organisation and Irrigation: Ideology, Planning and Practice in Sri Lanka's Settlement Schemes." In Understanding Green Revolutions: Agrarian Change and Development Planning in South Asia, edited by Tim P. Bayliss-Smith and Wanmali Sudhir, 315-338. Cambridge: Cambridge University Press.

Hetherington, Kregg. 2014. "Waiting for the Surveyor: Development Promises and the Temporality of Infrastructure." Journal of Latin American and Caribbean Anthropology 19(2): 195-211. https://doi.org/10.1111/jlca.12100.

Hughes, Diane O., and Thomas R. Trautmann. 1995. Time: Histories and Ethnologies. Ann Arbor: University of Michigan Press.

Larkin, Brian. 2013. "The Politics and Poetics of Infrastructure." Annual Review of Anthropology 42(1): 327-343. https://doi.org/10.1146/annurev-anthro-092412-155522.

Latour, Bruno. 1993. We Have Never Been Modern. Cambridge, MA: Harvard University Press.

Leach, E. R. 1959. "Hydraulic Society in Ceylon.” Past \& Present 15(April): 2-26.

Lynch, Caitrin. 2007. Juki Girls, Good Girls: Gender and Cultural Politics in Sri Lanka's Global Garment Industry. Ithaca, NY: Cornell University Press. 
Mahaweli Authority of Sri Lanka. 1978. "Mahaweli Settlement Area - H (Block 302, 303 and 304) Socio-Economic Survey - Maha 1977/78 Statistical Abstract." Colombo: Mahaweli Authority of Sri Lanka'disa.

. 1992. "Mahaweli Consolidation Project, System H, G, \& C Zone 2: Project Preparation Report." Colombo: Mahaweli Authority of Sri Lanka.

- 2003. "Mahaweli Restructuring and Rehabilitation Project (MRRP): Project Implementation Report." Colombo: Mahaweli Authority of Sri Lanka.

May, J., and N. Thrift. 2001. "Introduction.” In Timespace: Geographies of Temporality, edited by J May and N. Thrift, 1-46. London: Routledge.

Moore, Amelia. 2016. "Anthropocene Anthropology: Reconceptualizing Contemporary Global Change." Journal of the Royal Anthropological Institute 22(1): 27-46. https://doi.org/10.1111/1467-9655.12332.

Morton, Timothy. 2013. Hyperobjects: Philosophy and Ecology after the End of the World. Minneapolis \& London: University of Minnesota Press.

Mosse, David. 2003. The Rule of Water: Statecraft, Ecology and Collective Action in South India. Oxford: Oxford University Press.

Muggah, Robert. 2008. Relocation Failures in Sri Lanka: A Short History of Internal Displacement and Resettlement. London \& New York: Zed Books.

Munn, Nancy D. 1992. "The Cultural Anthropology of Time: A Critical Essay." Annual Review of Anthropology 21: 93-123.

Navaratne, M. W. U. 2000. "Management Arrangements for Mahaweli System H." Colombo: Mahaweli Authority of Sri Lanka.

People's Bank. 1979. "Water Rights and Irrigation Practices: A Study of Thorenagama Hamlet in the Mahaweli Development Area." Colombo.

Perera, Amantha. 2016. "As the Climate Shifts, Tradition Threatens Sri Lanka's Rice Harvest." Thomson Reuters Foundation. http://uk.reuters.com/article/ us-sri-lanka-water-farming-idUKKCN0XV109.

Pfaffenberger, Bryan. 1990. "The Harsh Facts of Hydraulics: Technology and Society in Sri Lanka's Colonization Schemes.” Technology and Culture 31(3): 361-397. https://doi.org/10.2307/3106052.

Reeves, Madeleine. 2016. "Infrastructural Hope: Anticipating 'Independent Roads' and Territorial Integrity in Southern Kyrgyzstan.” Ethnos (January): 1-27. https:// doi.org/10.1080/00141844.2015.1119176.

Scott, James C. 1998. Seeing Like a State: How Certain Schemes to Improve the Human Condition Have Failed. New Haven, CT \& London: Yale University Press. Shaviro, Steven. 2011. The Universe of Things: On Speculative Realism. Theory \& Event. Vol. 14. London: University of Minnesota Press. https://doi.org/10.1353/ tae.2011.0027.

Weeratunge, Nireka. 2000. "Nature, Harmony, and the Kaliyugaya." Current Anthropology 41(2): 249-268. https://doi.org/10.1086/300127.

Wittfogel, Karl. 1957. Oriental Despotism: A Comparative Study of Total Power. New Haven, CT \& London: Yale University Press. 